\title{
2. THE GEOLOGICAL AND GEOPHYSICAL SETTING NEAR DSDP SITE 395, NORTH ATLANTIC OCEAN1
}

\author{
D. M. Hussong, P. B. Fryer, J. D. Tuthill, and L. K. Wipperman, \\ Hawaii Institute of Geophysics, Honolulu, Hawaii
}

\begin{abstract}
A very detailed geological and geophysical study of the ocean crust on the upper flank of the Mid-Atlantic Ridge, near $23^{\circ} \mathrm{N}$, $46^{\circ} \mathrm{W}$, was conducted in preparation for drilling a deep multiple re-entry IPOD hole. The site was chosen to sample crust that is spreading at a slow rate and is near zero age. The site survey was designed to delineate a specific spot of well-defined age, uncomplicated by fracture zones, with geological and geophysical characteristics typical for the region, and with adequate sediment cover to allow deep drilling. The prime site recommendation, at $22^{\circ} 45.2^{\prime} \mathrm{N}$ by $46^{\circ} 07.3^{\prime} \mathrm{W}$, fits these specifications. This target was also desirable because the bulk of the IPOD-sponsored survey data was centered around it, and a multichannel seismic reflection line traversed it. Alternative sites were also considered.
\end{abstract}

\section{INTRODUCTION}

The first objective of the International Phase of Ocean Drilling (IPOD) of the Deep Sea Drilling Project is to determine the geological, geochemical, and geophysical character of ocean crust formed at mid-ocean spreading ridges. A series of drill holes along the Mid-Atlantic Ridge (MAR), from near Iceland south to approximately $22^{\circ} \mathrm{N}$ latitude, was planned to compare the crust being generated near an anomalous ridge (Iceland) with that originating near a normal slow-spreading ridge $\left(22^{\circ} \mathrm{N}\right)$. At the same time, a series of holes in near zero-age crust at $22^{\circ} \mathrm{N}$ was planned along a "flow line" (a transect parallel to local fracture zones) trending west into increasingly older crust, eventually extending the sampling to crust of apparent Jurassic date off the eastern United States coast. This age-transgressive transect was designed to test the evolution of crust formed at one point in the spreading ridge. The intersection of these two series of holes was designated Atlantic Site $5^{2}$, and was positioned (Figure 1) on the upper western flank of the MAR near $22^{\circ} \mathrm{N}$ latitude, as close as possible to the spreading ridge crest. The importance of the hole as a tie point for the Atlantic transects, as well as for subsequent comparisons with a similar eastern Atlantic site and with sites on fast-spreading ridges planned for the Pacific Ocean, prompted the Ocean Crust Panel of IPOD to designate Atlantic Site 5 a high priority "Very Deep" (meaning, at the time, a multiple re-entry hole penetrating on the order of $1000 \mathrm{~m}$ of basement) site.

\footnotetext{
${ }^{1}$ Hawaii Institute of Geophysics Contribution No. 833.

${ }^{2}$ Now designated Survey Area AT-5.
}

Before the Hawaii Institute of Geophysics (HIG) survey (Kana Keoki 74-01-09, Leg 7) described in this paper, only reconnaissance data existed for the region of proposed Atlantic Site 5. Bathymetry and magnetics along two Lamont-Doherty Geological Observatory (L-DGO) tracks (from cruises Vema 2501 and 2503) traversed the area. Most of the existing information about Atlantic Site 5 came from a pre-satellite navigation survey conducted by the Woods Hole Oceanographic Institution (Chain 44), consisting mainly of tracks normal to and across the MAR axial valley and high plateau region, spaced at intervals of about 5 nautical miles (n.m.). The Woods Hole data, obtained mostly east of the Site Atlantic 5, were described by van Andel and Bowin (1968). Based on those data, this area of ocean crust was known to be about 4 to 10 million years old, and to have only isolated pockets of sediment cover and very rough bathymetry, ranging from 2400 to 4600 meter depth. The van Andel and Bowin (1968) work further suggested that to locate adequate sediment cover for spudding in and placing the re-entry core (a minimum of $60 \mathrm{~m}$, but preferably more than $100 \mathrm{~m}$ ) the site would have to be over 60 $\mathrm{km}$ away from the ridge crest median valley. The ocean crust, if formed at the ridge crest and spreading at a half-rate of $1.4 \mathrm{~cm} /$ year (van Andel and Bowin, 1968), would then have an age of over 4 m.y. under the first appreciable sediment pockets.

Just before the HIG survey, a multichannel digital seismic reflection profile, contracted by IPOD and the U.S. Geological Survey to Digicon Corp., was shot from off Cape Hatteras, through the Atlantic Site 5, to the MAR crest. The resultant data helped define the depths of sediment ponds in the area, but did not delineate layering in the crystalline crust. 


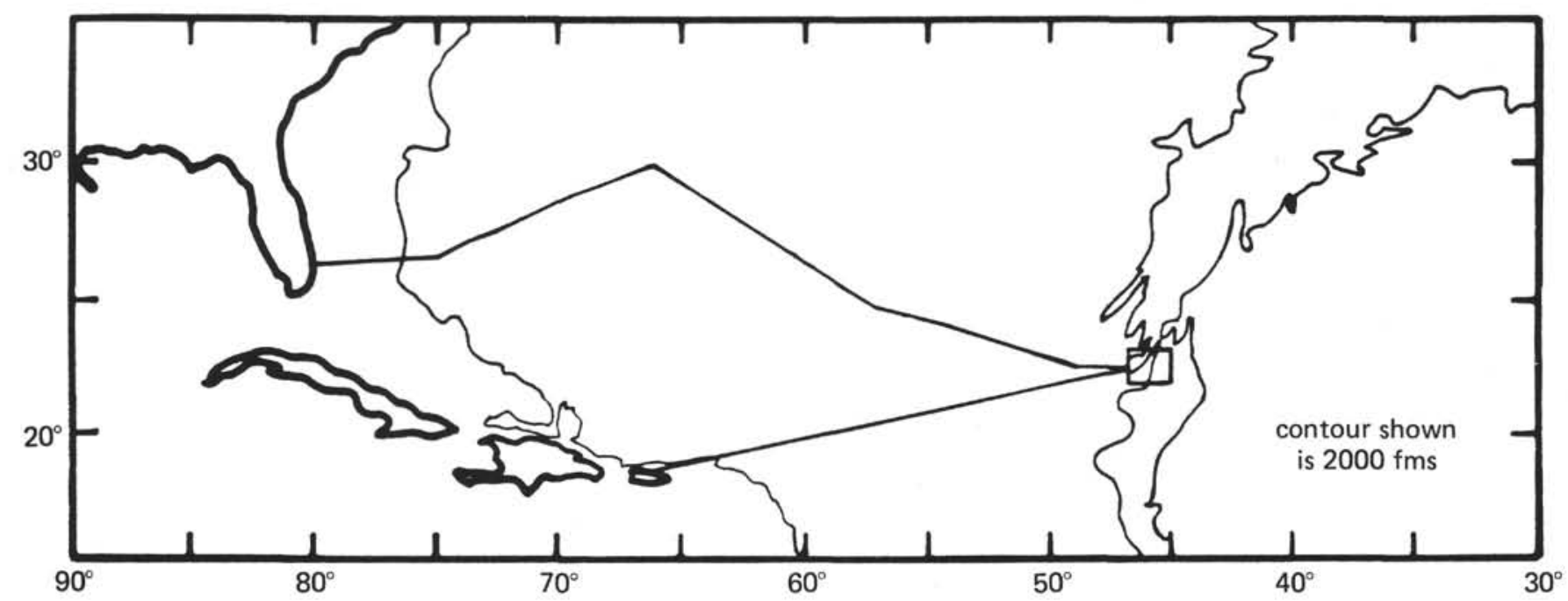

Figure 1. Cruise track of Kana Keoki 740109 Leg 7, from Miami to San Juan, Puerto Rico. Contour is 2000-fm isobath.

\section{DATA ACQUIRED DURING KK 74-01-09, LEG 7}

The R/V Kana Keoki conducted a detailed 22-day survey of Atlantic Site 5 during Cruise 74-01-01, Leg 7. Navigation during this survey was all satellite-controlled. The resultant geophysical and geological data sets are described below and are deposited with IPOD and NGSDC.

The cruise track within the site survey region is shown in Figure 2. After devoting several days to completing a basic geophysical profiling grid, four sediment ponds were chosen as potential drill sites. These were designated (Figure 2) A, B, C, and North ${ }^{3}$. They were chosen for extra work because: "A" was the largest pond which seemed to be on magnetic anomaly 5; "North" and "B" were on the Digicon CDP line and were large and relatively undisturbed sediment pockets; and "C" seemed to be the major deep sediment pond located on the youngest crust. Further geophysical profiling was then conducted to further delineate these site areas. Subsequent geologic sampling was also concentrated in these sediment areas. The resultant dense track lines in Figure 2 identify the location of the candidate sediment ponds.

\section{Bathymetry}

A reduced-scale bathymetric map of the survey area, based on $3.5-\mathrm{kHz}$ reflection data from KK $74-01$ 09, Leg 7, was prepared (Figure 3 ). It shows that the local water depths range from over 4600 to less than 2400 meters. This rough topography is characterized by irregular ridges trending north-south. The topographic grain is illustrated in Figure 4, a comparison of a representative north-south seismic reflection record with a typical east-west record.

A general east-west-trending bathymetric low, running across the survey area and through North Pond at about latitude $22^{\circ} 45^{\prime} \mathrm{N}$, suggests a fracture zone. It

\footnotetext{
${ }^{3}$ Later designated target pond A by Site Survey Management.
}

does not, however, have corresponding magnetic anomaly offsets.

The Mid-Atlantic Ridge high plateau, or crest range (terminology of van Andel and Bowin, 1968), is apparent on the eastern side of the survey area only in the central portions of the region HIG surveyed (between about $22^{\circ} 30^{\prime}$ to $23^{\circ} 00^{\prime} \mathrm{N}$ latitude). On the bathymetric map the high plateau is delineated only by a somewhat less rugged sea floor with average depths of about 3 $\mathrm{km}$.

The bathymetry around North Pond shows it to be a closed basin. It is bounded on the southeast by an unusually steep scarp and on other sides by slopes that are typical for the survey area (approximately 5 to 6 degrees).

\section{Sediment Distribution}

The location of sediments at Atlantic Site 5 is shown as hachured areas in Figure 5. In general, the sediment pockets are thin and are confined to bathymetric lows. in some places the sediments are vertically displaced, possibly by faulting consequent to recent tectonic activity (Figure 6).

A sediment isopach map of North Pond (Figure 7), shows that as much as $0.3 \mathrm{sec}$ (two-way travel time) of sediment occurs in the center of the southern portion of North Pond. This portion of the pond shows no obvious signs of recent tectonic disruption.

The northeastern portion of North Pond also has fairly deep sediment, but it may have been subject to recent faulting. A step, only a few meters high, can be seen in the sediment in the far northeastern corner of the pond. It is readily observed on the $3.5-\mathrm{kHz}$ seismic profile.

\section{Magnetics}

The residual magnetic field, corrected for the IGRF (using the 1965 coefficients), is shown as Figure 8. The anomaly pattern has a definite "grain," although it is disrupted by bathymetric irregularities. The average grain trends approximately $\mathrm{N} 10^{\circ} \mathrm{E}$, as can also be seen 


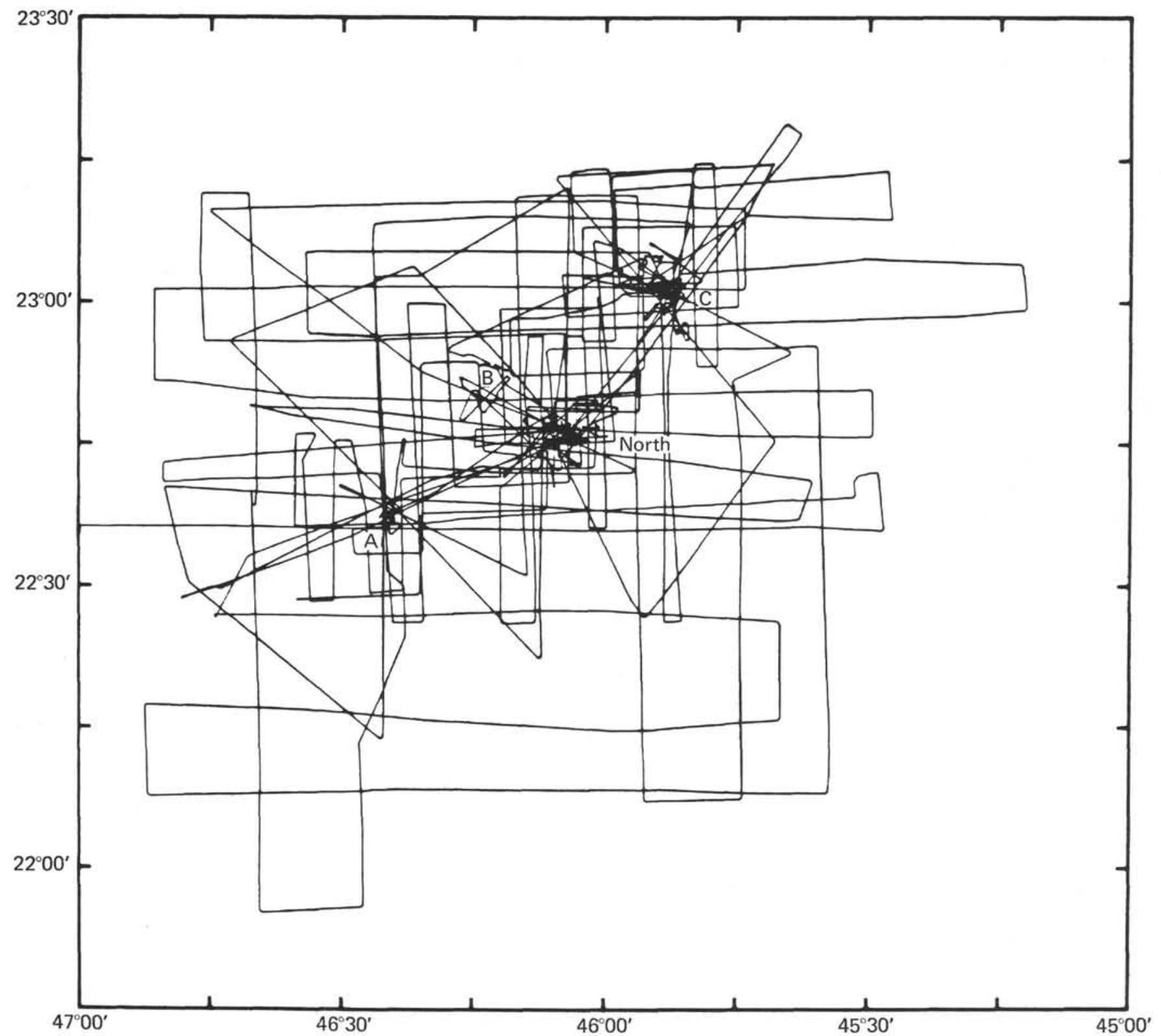

Figure 2. Atlantic Site 5 survey area. Track of $R / V$ Kana Keoki. Labeled sediment ponds are actually beneath areas of dense ship tracks.

in the anomaly profile and isochron map (Figure 9). The anomalies as correlated have slightly different trends in various parts of the area. Small unmapped fracture zones are probably responsible for some slight offsets from profile to profile. There do, however, appear to be well-determined differences in average trend, on the order of $10^{\circ}$. This may imply that parts of this area were formed during periods of oblique spreading on the MAR. The correlations of these anomalies with the reversal time scale are only fair-a common problem over slowly spreading rises. The calculated half-rate in the survey area averages 1.7 $\mathrm{cm} /$ year. Although not well determined, it is possible that the spreading rate increased from $1.6 \mathrm{~cm} /$ year to about $1.8 \mathrm{~cm} /$ year between 6 and 8 m.y.B.P. (or about the time of anomaly 4 ).
Two fracture zones were tentatively hypothesized on the basis of interruptions in the magnetic anomaly correlations from track to track. The positions and azimuths of these fracture zones were then interpreted considering both the bathymetry and the magnetic anomalies, including those on tracks not shown in Figure 8 . The northern fracture zone shows up in the bathymetry (Figure 3 ), but the southern one has very little topographic expression.

The northern fracture zone appears to have begun between 6 and 7 m.y.B.P., but because of the lack of highly characteristic anomalies we regard this interpretation as extremely tentative. If true, it requires the birth of a rise-rise transform fault, which would have required asymmetric accretion in the form of a rise axis jump and/or asymmetric spreading. The increase in 


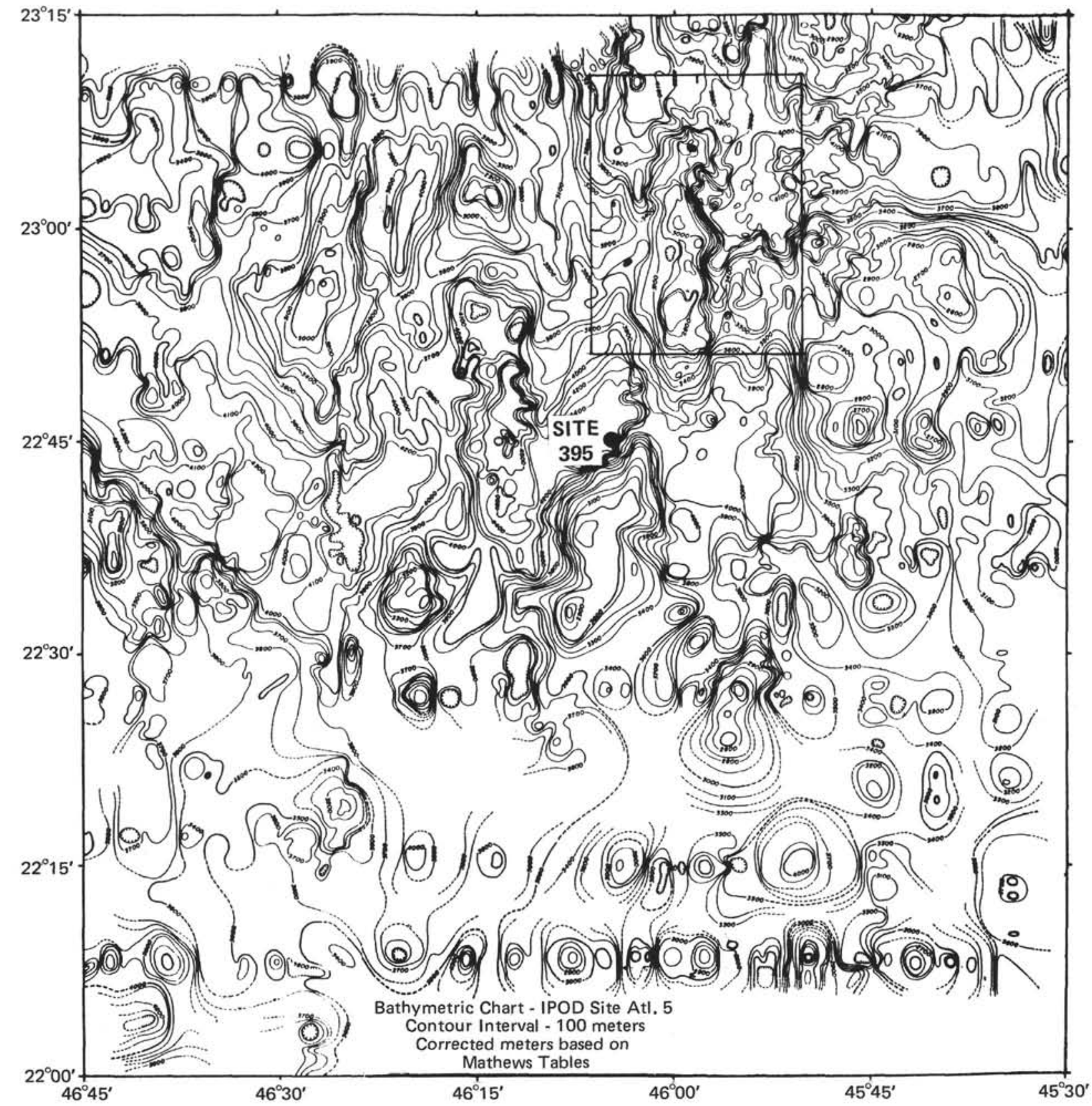

Figure 3. Bathymetric contour chart. Contour interval is 100 meters. Enclosed area is Figure 13.

anomaly offset between 7 and 8 m.y.B.P. on the southern fracture zone similarly requires some sort of asymmetric accretion. Once again, the indistinctive anomalies make this conclusion more tentative than this data density should permit.

The "North Pond" area appears to be relatively free of the complications of fracture zones and anomaly trend changes. It is located on the flank of anomaly 4.

\section{Gravity}

Gravity data were collected using a LaCoste and Romberg S-33 gravimeter. The mean line crossing error is $3.1 \mathrm{mgal}$.
The FAA field for the region of Atlantic Site 5 is shown in Figure 10. In general, the FAA field follows bathymetric trends and indicates that most of the major anomalies are caused by sea-floor topography and density distribution in the uppermost crust.

\section{Crustal Seismic Refraction}

The seismic refraction data were collected using three types of receivers: 14 U. S. Navy SSQ-41A sonobuoys that were modified at HIG to provide 3 days of operation (compared with the 3 hours available from the standard buoys); 2 pop-up ocean-bottom seismometers (OBS) that tape-record the seismic data on the seafloor; and 2 OBS's that are connected by a 


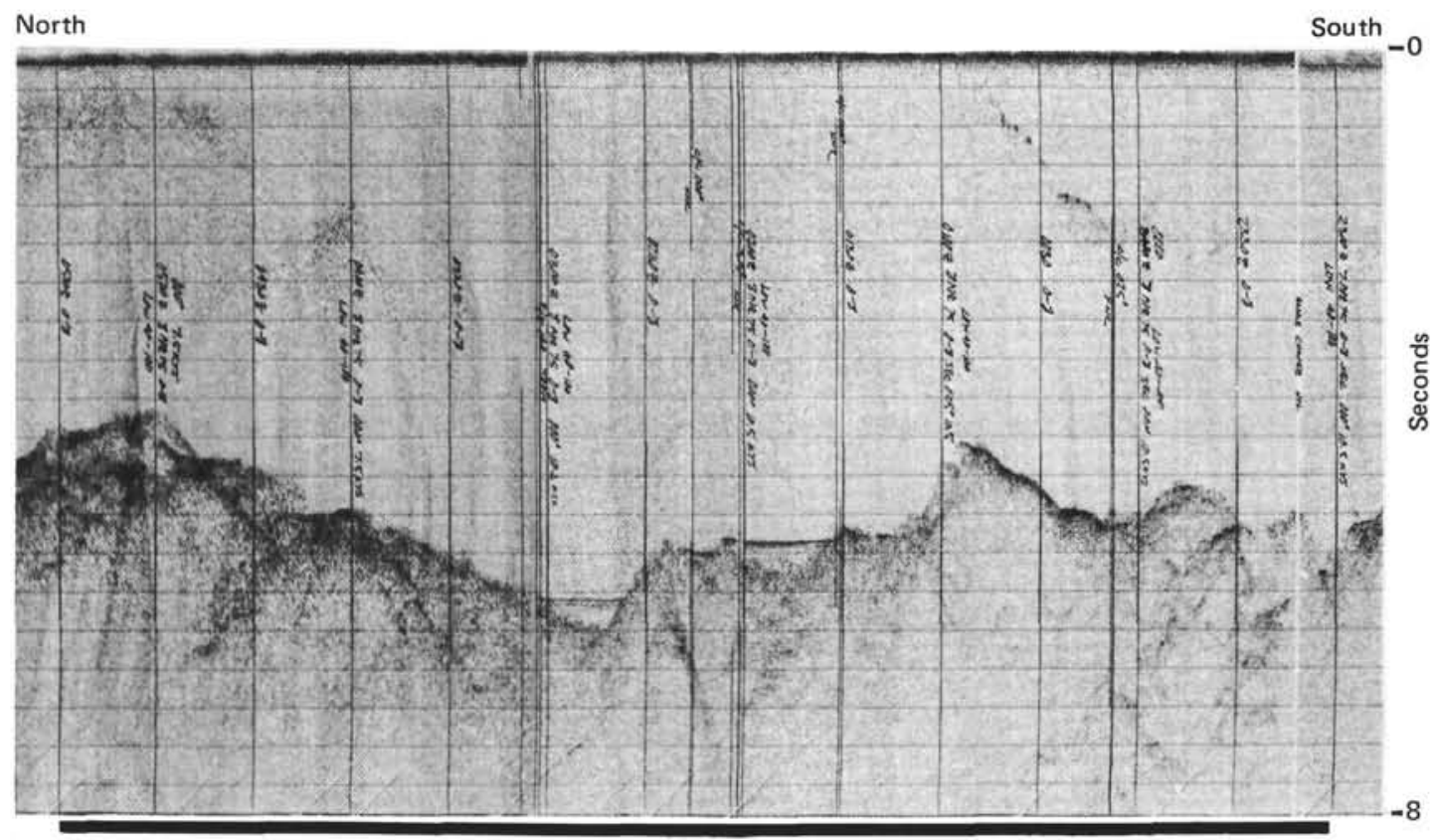

$115 \mathrm{~km}$

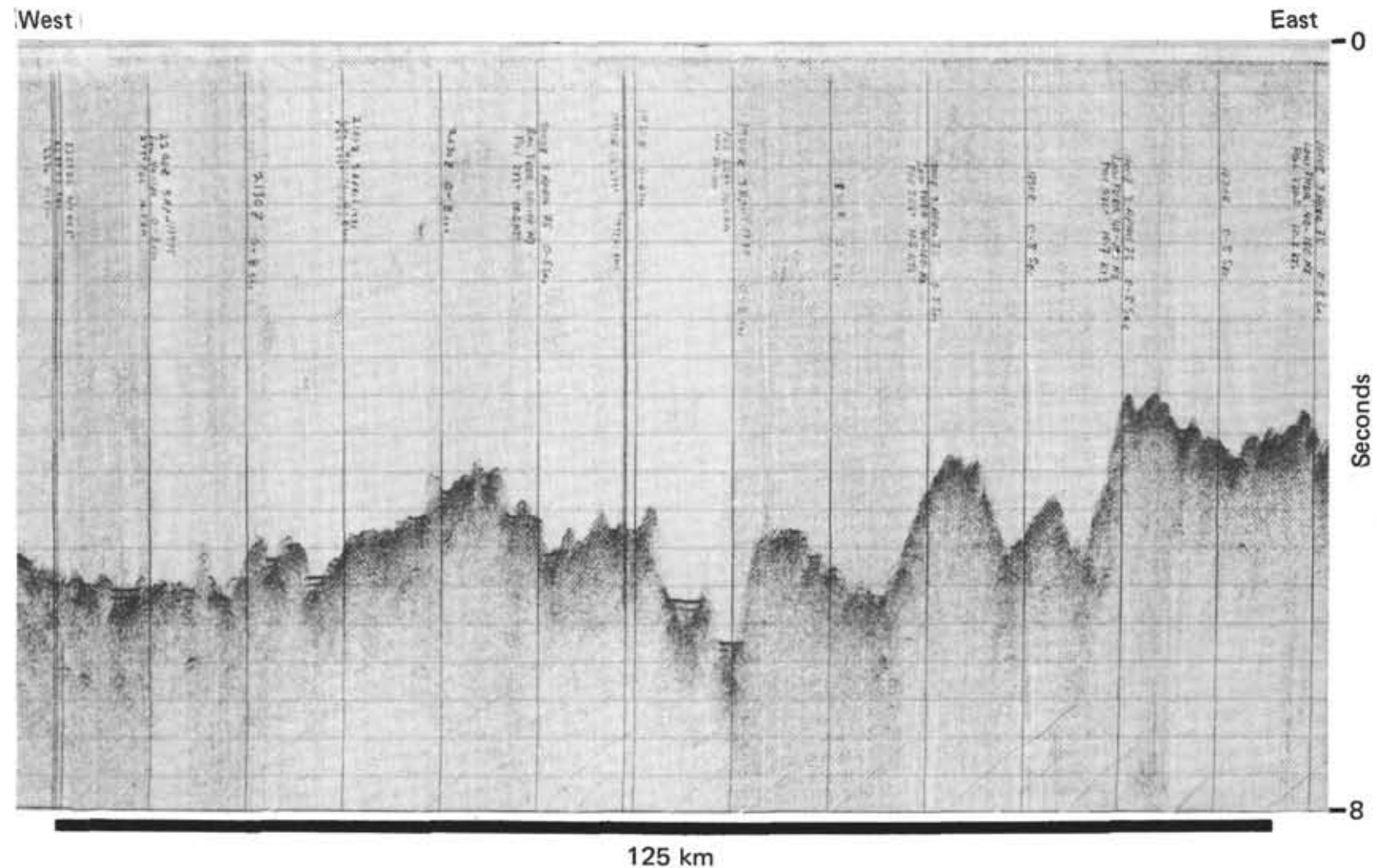

Figure 4. Topographic grain in the survey area. The top reflection profile was taken on a north-south line. The bottom reflection profile was acquired on an east-west line.

telemetering cable to a surface transmitter, which relays the seismic data by radio to the shooting ship. These tethered OBS's had limited radio range, so that data were transmitted to the shooting ship only within $30 \mathrm{~km}$ of the OBS. A complete description of these instruments has been published by Sutton et al. (1977).

Locations of the OBS's and modified sonobuoys are shown in Figure 11. The internal time standard on one of the OBS's failed, so only three units gave useful data, and are described further. Table 1 lists the results of the refraction experiments.

All the seismic arrivals were corrected for shot depth. A crude topography correction, which assumed that the rays traveled vertically below the shot and receiver, was then applied to all the arrivals. When a reasonable estimate of the refracting velocity of each arrival could be made, the topographic corrections were revised to correspond to bathymetry relief at the 


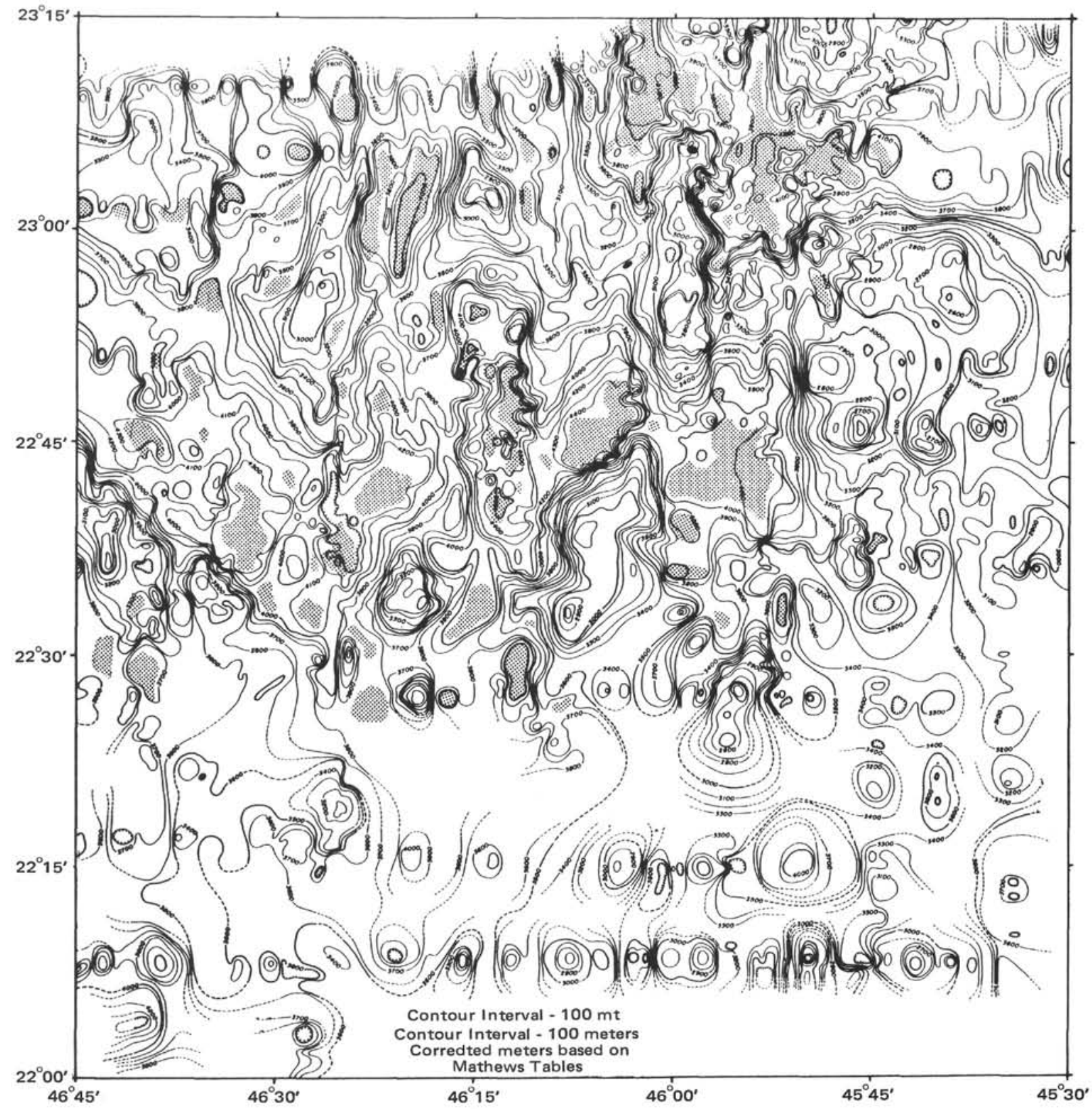

Figure 5. Sediment distribution. Sediment observed on reflection profiles is indicated by hachured areas on the bathymetric contour map.

point on the ocean floor where the rays actually should have traveled. This bathymetric correction greatly reduced scatter in the resultant travel-time plots. A velocity of $4.5 \mathrm{~km} / \mathrm{sec}$ was used for making all seismic topographic corrections.

The OBS data were also corrected to the ocean surface, to permit reversal of these results with sonobuoy data.

The refraction models are very inconsistent. We have attempted to improve the regularity of the various layer depths and velocities beneath the area of Atlantic 5 Site by various schemes of correction for surface irregularity, but have had little success. We feel that the crustal inhomogeneity demonstrated by the refraction models reflects the complex geology in the region.
A smoothed block diagram (Figure 12) represents our best approximation of the generalized crustal structure beneath North Pond. The block diagram was prepared to aid in drilling strategy, and is greatly oversimplified. When compared with Table 1 , it is apparent that the crust depicted in Figure 10 should be far more irregular and disordered. The moho is also incoherent and poorly observed, and the assignment of a velocity of $7.95 \mathrm{~km} / \mathrm{sec}$ and a depth of only $8 \mathrm{~km}$ to this interface should be considered tenuous.

The crustal column on the right side of Figure 10 represents our generalized model directly beneath the "X" marked in North Pond.

Throughout the survey area of Atlantic Site 5, the crust beneath the low-lying sediment ponds has deeper 


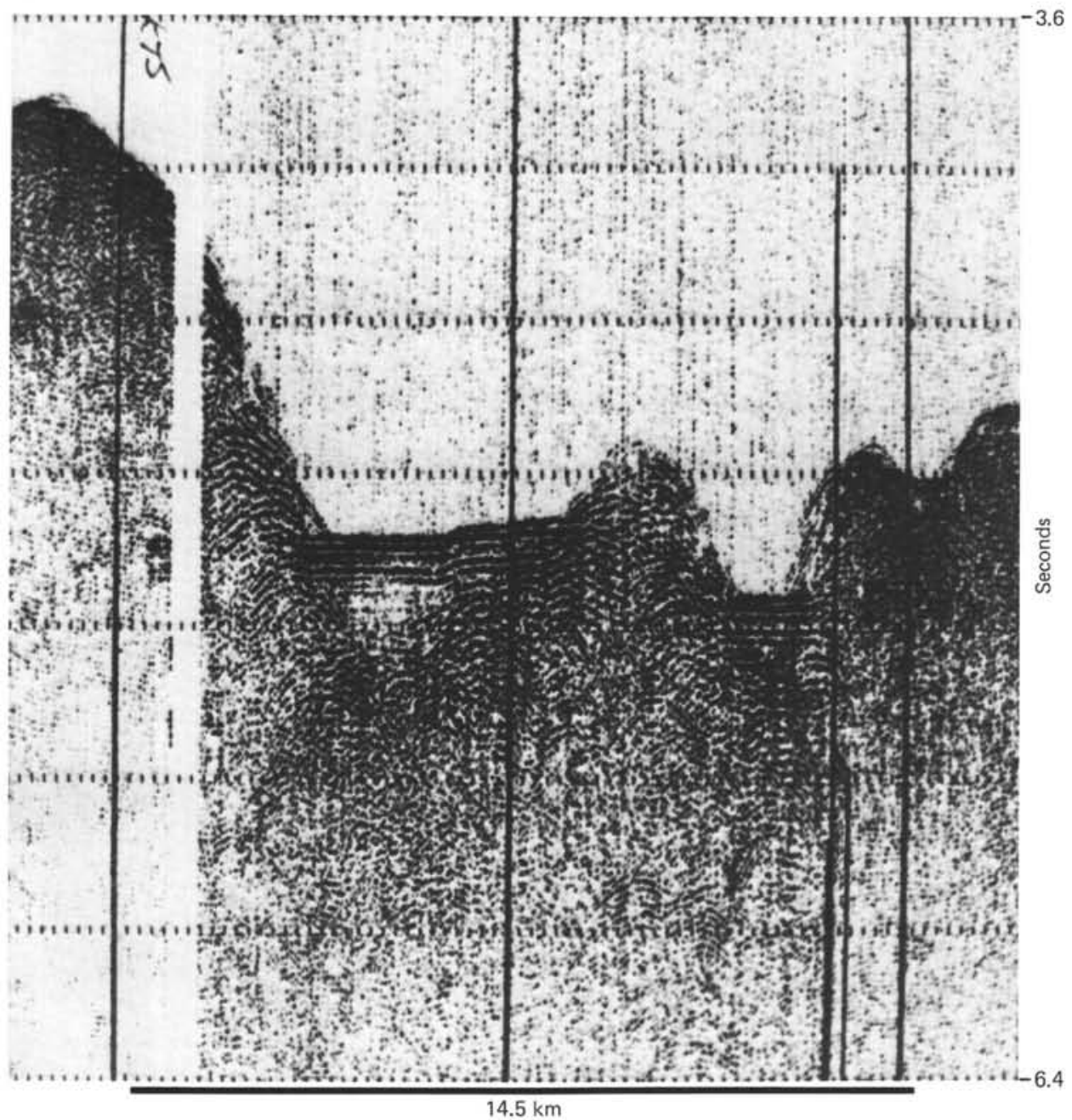

Figure 6. Example of post-depositional faulting of ponded sediments.

and thinner layers, with higher velocities, than the crust found beneath the bathymetric highs. For purposes of drilling, this means that the top of layer 3 is somewhat farther from the ocean surface (about $5.4 \mathrm{~km}$ ) beneath the bathymetric lows than it is beneath many of the ridges (under some shallower places, layer 3 is less than $5 \mathrm{~km}$ from the ocean surface), but to reach it one would have to drill through more crustal rocks. The depth to layer 3 is about the same under " $A$ " pond, and is around $5.6 \mathrm{~km}$ beneath " $\mathrm{B}$ " pond, where the water is deeper. Layer 3 may be shallower beneath " $\mathrm{C}$ " pond (about $5.0 \mathrm{~km}$ ), but the interface is poorly determined and is based only on sonobuoy data.

The velocities of both layers 2 and 3 are greater beneath all the pond areas than they are beneath the bathymetric highs. The crustal velocities are also greater beneath North Pond than almost anywhere else in the area of Atlantic Site 5. The cause of this is not apparent, but is may not be significant, considering the large scatter of Layer 2 velocities throughout the region of Atlantic Site 5.

\section{Seismicity}

During the four and a half days of OBS deployment, 10 natural earthquakes were recorded. These events can be subdivided into two sets, earthquakes occurring about $44 \mathrm{~km}$ from North Pond and those occurring about $80 \mathrm{~km}$ from North Pond (because of the limited data-transmission range of the telemetering OBS, and the clock failure on one of the pop-up OBS, useful earthquake data were only acquired on one OBS).

The $80-\mathrm{km}$-range activity is probably associated with the MAR crest. The 44-km-range activity, however, must be away from the spreading center, and may be associated with the secondary, on-plate activity that causes the faulted sediments observed in the area of Atlantic Site 5.

A paper being prepared by J. Kasahara, D. M. Hussong, and G. H. Sutton for Earth and Planetary Sciences Letters describes these earthquakes in detail.

\section{Heat Flow}

All heat-flow determinations are compiled in Table 2. The thermal gradient was measured with a free-fall instrument that measures both absolute temperature and temperature differential across thermistors at a 1-meter spacing.

Thermal conductivity was measured from free-fall gravity-core samples acquired at each heat-flow station. 


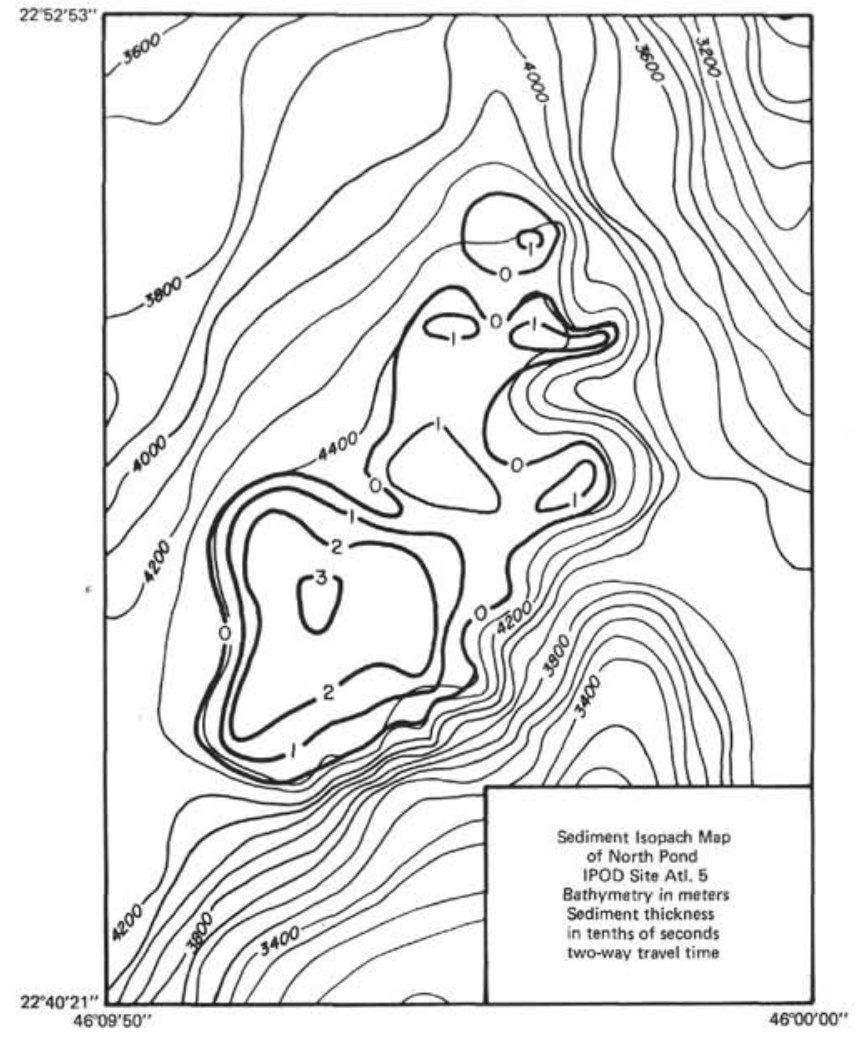

Figure 7. Sediment isopach map of North Pond. Heavy lines are sediment thickness in tenths of seconds of twoway travel time. Thin lines are bathymetric contours in meters.

If TG 12 (which yielded an anomalously high heatflow value of $2.86 \mathrm{HFU}$ ) is not used, all the stations are within $0.10 \mathrm{HFU}$ of an average of $0.88 \mathrm{HFU}$. This value is lower than might be expected for such young oceanic crust, but it seems to be remarkably uniform around the site. The data are, of course, biased by the necessity of always measuring the heat flow in isolated large sediment ponds.

\section{Sediment Cores}

Four oriented piston cores with 6 to 12 meters of Pleistocene to Recent foraminifer sediment were recovered in the survey area. Ten free-fall gravity cores were recovered, and each contained about a meter of foraminifer sediment. No sediment older than Pleistocene was recovered by coring. The cores have all been opened and sampled, and are now stored at HIG.

\section{Dredged Rock Samples}

The number of rock samples obtained by dredging at Atlantic Site 5 was disappointing (Table 3). The low percentage of successful dredge hauls suggests that the scarps and slopes in the region are relatively smooth and may be largely covered by a thin (undetectable by seismic reflection methods) sediment cover.

The first dredge haul (RD-1) was made on the upper slopes of an elongate seamount at $23^{\circ} 02.9^{\prime} \mathrm{N}$, $46^{\circ} 00.1^{\prime} \mathrm{W}$ (Figure 13). This was the largest recovery and the only haul to yield relatively fresh samples. We attempted additional hauls on the $24^{\circ}$ slope east of RD-1 (see Figure 14): RD-4 at the base of the slope, in what we believed to be a talus pile, RD-2 about halfway up, and RD-3 at the break in slope on the top. We had expected more success in dredging the fairly steep slopes, and found it interesting that in this series the only haul to produce any samples was that from the small depression near the top of the seamount. We did succeed in retrieving, in RD-5, some samples from a nearby $20^{\circ}$ slope, but they were extremely altered and essentially useless for petrographic or geochemical work.

Material brought up in RD-1 may be classified into three types: semi-indurated foraminifer ooze, conglomerate, and basalt fragments. Foraminifers contained in the ooze range from Zone N.16 to N.21 (Table 4) making the probable date of the ooze late Miocene. The conglomerates are composed of rounded to subrounded pebbles of extremely altered volcanic rock. It is difficult to determine with certainty what the pebbles were initially, but some appear to contain altered elongate phenocrysts. These and some others in which there are no discernible "phenocrysts" have a greenish cast and may be altered basalt fragments. In addition, there are orange pebbles, which could be palagonitized glass. The matrix of the conglomerate is a mixture of brown clay, primarily montmorillonite, and manganese. Manganese encrustation on the conglomerates is much thicker than on any of the other samples brought up in the dredge. One of the samples, 1.6 , shows a contact between ooze and the conglomerate. Another of the rocks, 1.8, a palagonitized vitrophyre, was partially coated with a thin film of unlithified ooze. This sample was probably broken from the surface of a flow and partially embedded in a pocket of soft ooze. The general appearance of the sample suggests that the lithified ooze, the vitrophyre, and the conglomerates were dredged from the surface and margin of a sediment pocket. The basalt fragments came, we believe, from somewhat farther up-slope.

The basalt samples fall into two textural categories, porphyritic and aphyric (Table 5). A gradation between groundmass textures occurs in some of the samples, and is most strikingly displayed in Sample 1.B2. This rock has a glassy rind containing a few elongate phenocrysts of plagioclase surrounded by dark red-brown halos. The same red-brown material occurs as varioles in the glass which become more numerous toward the interior of the rock, until they coalesce and the acicular plagioclase microlites in their interiors become large enough to be easily recognized. Thus, the texture grades from vitrophyric to variolitic toward the center of the rock. In addition to the varioles, there are patches of microlites which also become more numerous toward the interior of the rock. The microlites are probably clinopyroxene. Similar texture and mineralogy is evident in many pillow basalts, for example those from DSDP Site 163 in the central Pacific (Yeats et al., 1973) and pillow basalts dredged from the Nazca plate (Palmiter, 1976, per- 


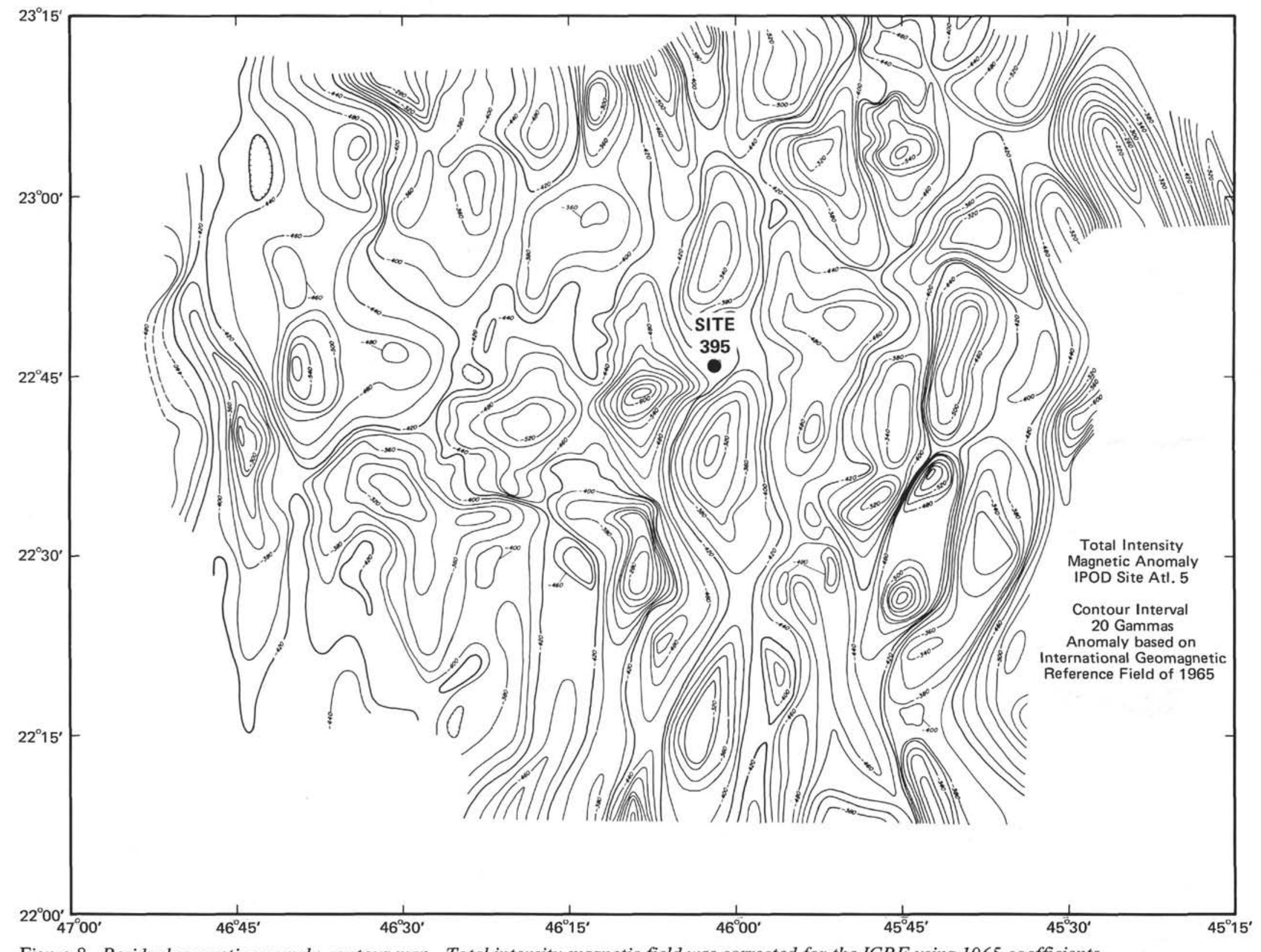

Figure 8. Residual magnetic anomaly contour map. Total intensity magnetic field was corrected for the IGRF using 1965 coefficients. 


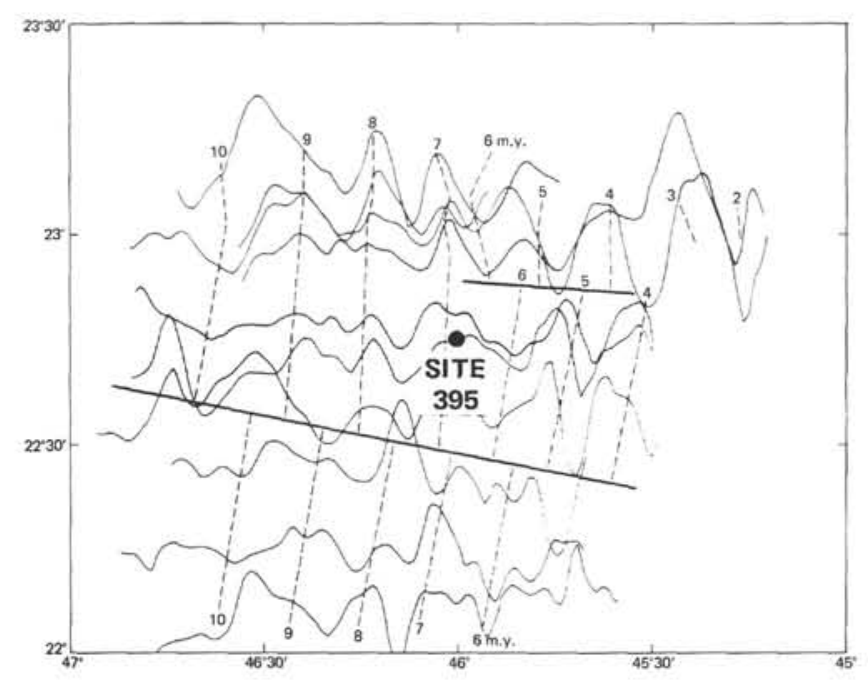

Figure 9. Major magnetic profiles, with interpreted crustal age isochrons in millions of years. The dark lines offsetting the isochrons are probably fracture zones.

sonal communication), as well as in some of the aphyric samples retrieved from DSDP Hole 395 (this volume). The rocks with variolitic texture most likely represent fragments of pillow interiors. One of the samples, 1.13 , has a gradation from variolitic to hyalopilitic texture. It and the other samples of similar texture probably also represent pillow fragments. In fact, the only sample with a texture not indicative of pillow basalt is 1.15 , a porphyry with large plagioclase and small augite phenocrysts in an intergranular groundmass composed of plagioclase, pyroxene, and ore minerals.

The mineralogy of the rocks is reported in Table 5 . The secondary minerals included under the column "other" are primarily bowlingite, chlorite, and zeolite, and occur as vesicle fillings and as alteration products of the mafic minerals and the glass. The plagioclase in these rocks seems to be well preserved for the most part, but the mafic minerals are almost wholly replaced and the glass is generally altered to palagonite or to a combination of fine-grained fibrous minerals. The choice of samples to be analyzed for major elements was based on the relative freshness of the glass. The results of these analyses are presented in Table 6.

The four samples analyzed fall within the field of alkalic basalt on a silica-alkali diagram (Figure 15), although they are slightly depleted in silica, with respect to average oceanic alkalic basalt. The alkalic nature of the basalts is also indicated by their proximity to the alkalic differentiation trend on an AFM diagram (Figure 16).

\section{POST-SURVEY DRILL-SITE RECOMMENDATIONS}

The following drill-site recommendations were made to IPOD in October 1975, on the basis of the survey described in this paper.
TABLE 1

Seismic Refraction Results

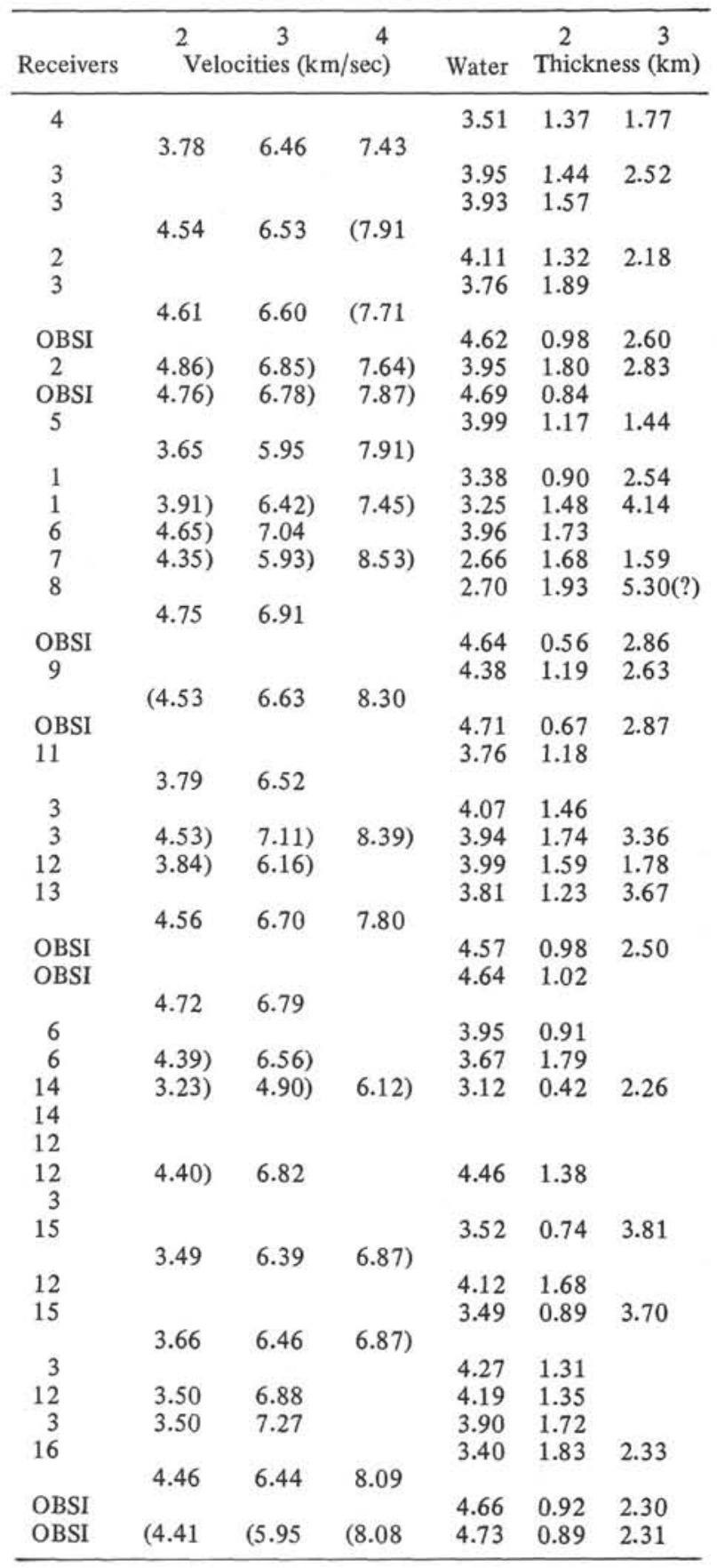

\section{Primary: North Pond}

On the basis of the HIG data, we would recommend drilling in North Pond near $22^{\circ} 45.2^{\prime} \mathrm{N}$ and $46^{\circ} 07.3^{\prime} \mathrm{W}$, for the following reasons:

1) The sediment pond is large, has 200 to 300 meters of sediment, and apparently has not been subject to recent faulting around the suggested site. The drill ship should not, however, move to the northeast portion of the pond, where signs of recent faulting occurred. 


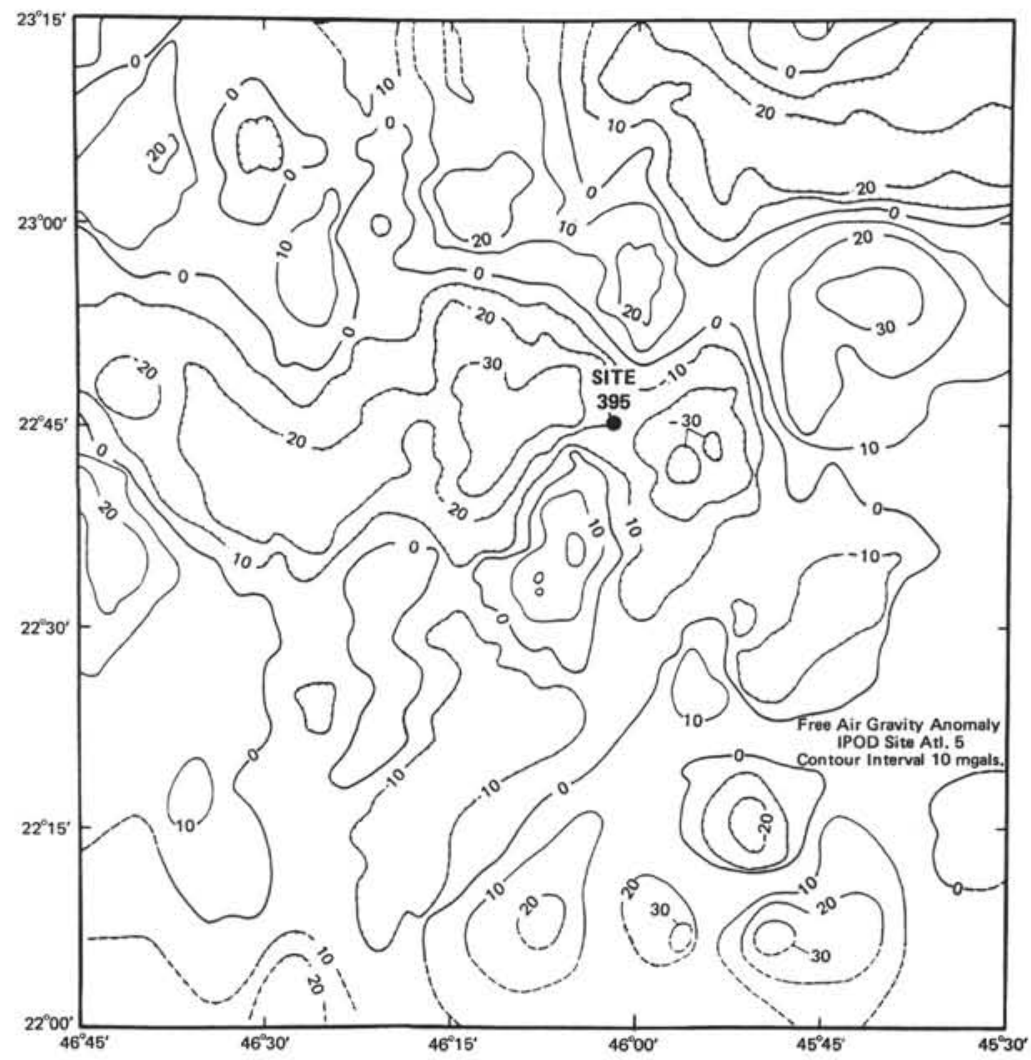

Figure 10. Free-air anomaly contour map. Contour interval is 10 milligals.

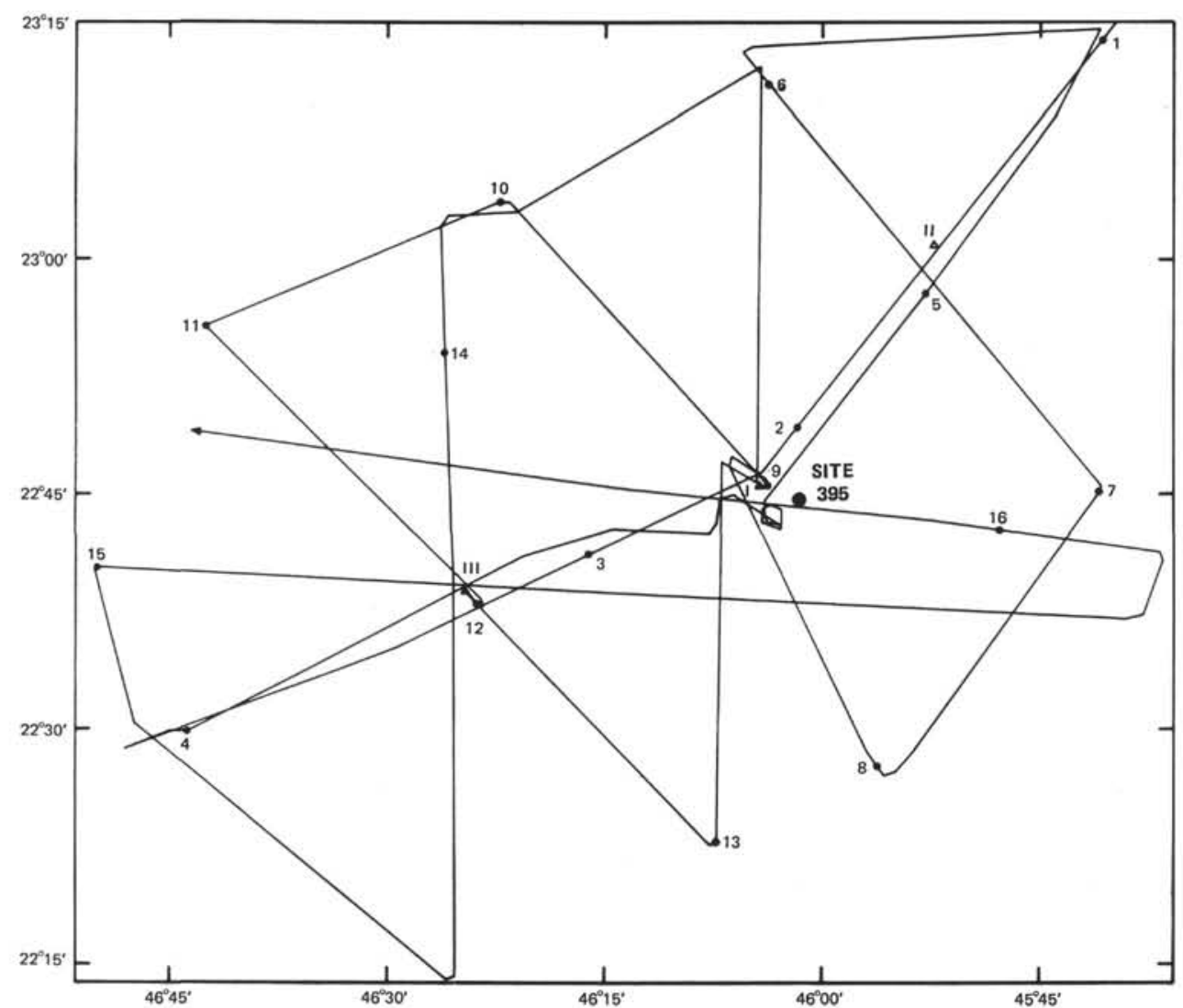

Figure 11. Lines along which shots were fired for refraction receiving stations. Sonobuoy receivers are labeled 1 to 16 and OBS's are labeled I to III. 


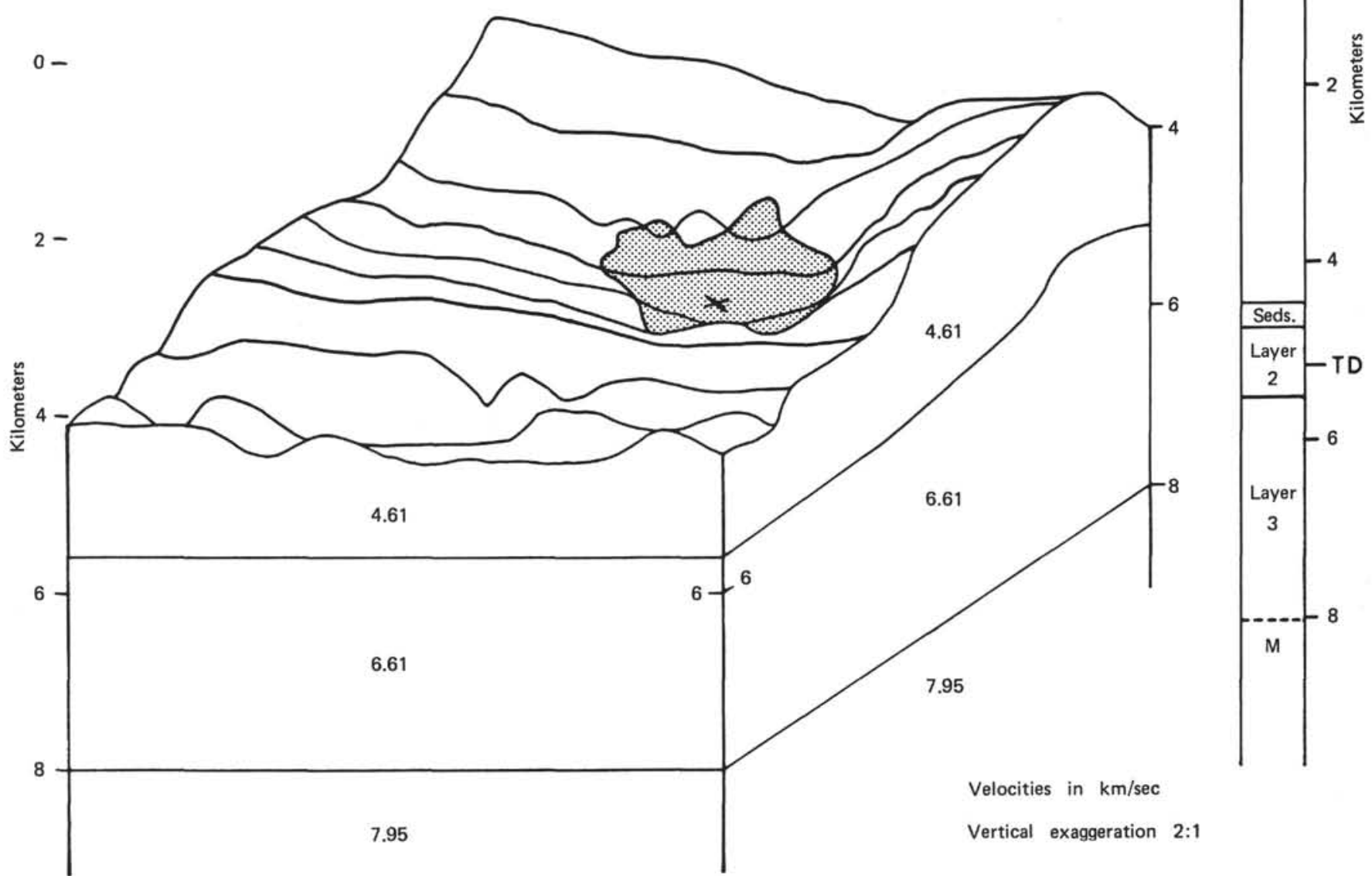

Figure 12. Generalized crustal structure under North Pond. The crustal column on the right represents the generalized model directly beneath the " $X$ " marked in North Pond.

2) On the basis of the magnetic interpretation, no major spreading anomaly offset occurs at North Pond. Although many small undetected fracture zones undoubtedly cross the survey area of Atlantic Site 5, we hope that the magnetic continuity increases the chance that the crustal rocks at the drill site are not fractured.

3) Although North Pond is on crust that apparently was formed at the time of anomaly 4 (not the target anomaly 5), the drill site seems far enough up the flank of the anomaly that we hope it will not penetrate rock emplaced during a time of magnetic field polarity reversal. Our predicted age here is 7.3 m.y.

4) The oceanic crustal structure is very disorganized under the site, but this seems to be true throughout this area of young crust. The best OBS data, including shear wave arrivals, was obtained in North Pond. It does seem likely that the 6700-meter Glomar Challenger drill stem can penetrate through layer 2 and about a kilometer into layer 3 .

5) The local gravity and magnetic fields show no obvious anomalous features.

6) Heat-flow stations nearest the drill site are within $0.10 \mathrm{HFU}$ of the average heat flow (disregarding one very high measurement) measured during the survey.
7) The Digicon multichannel reflection line runs through North Pond, and the data points of our survey are concentrated around North Pond. Far more information is available about this pond, therefore, than about any other portion of the surveyed region. This large body of information will make the samples obtained from drilling more useful, in that they can be more confidently related to the local and regional geologic and geophysical setting.

Only two disadvantages of choosing the North Pond site come quickly to mind; neither is compelling.

1) The site is not on the originally targeted magnetic anomaly 5 .

2) The pond lies in the middle of a regional eastwest-trending bathymetric (and, of course, free-air gravity) low. As mentioned, the magnetics do not indicate that this low is the expression of a major fracture zone.

\section{Secondary: "A" pond}

As an alternative to North Pond, a site at "A" pond might be considered near $22^{\circ} 37.5^{\prime} \mathrm{N}$ latitude and $46^{\circ} 25^{\prime} \mathrm{W}$ longitude. This site is far less attractive than North Pond, and has only the following advantages. 
TABLE 2

Heat Flow

\begin{tabular}{lcccccc}
\hline Station & $\begin{array}{c}\text { Latitude } \\
(\mathrm{N})\end{array}$ & $\begin{array}{c}\text { Longitude } \\
(\mathrm{W})\end{array}$ & $K$ & HFU & $\begin{array}{c}\text { Depth } \\
(\mathrm{m})\end{array}$ & Remarks \\
\hline FFTG 1 & $22^{\circ} 51.6^{\prime}$ & $46^{\circ} 5.4^{\prime}$ & $2.34 \pm 0.0$ & 0.91 & 4312 & (F.P.) \\
FFTG 2 & $22^{\circ} 51.5^{\prime}$ & $46^{\circ} 12.6^{\prime}$ & $2.37 \pm 0.04$ & 0.75 & 4312 & (F.P.) \\
FFTG 5 & $22^{\circ} 46.8^{\prime}$ & $46^{\circ} 15.2^{\prime}$ & $2.43 \pm 0.03$ & 0.92 & 4457 & (F.P.) \\
FFTG 7 & $23^{\circ} 03.0^{\prime}$ & $45^{\circ} 57.4^{\prime}$ & $2.28 \pm 0.09$ & 0.93 & 4022 & (F.P.) \\
FFTG 11 & $22^{\circ} 46.7^{\prime}$ & $46^{\circ} 07.0^{\prime}$ & $2.37 \pm 0.03$ & 0.87 & 4466 & (F.P.) \\
FFTG 12 & $22^{\circ} 47.0^{\prime}$ & $46^{\circ} 06.8^{\prime}$ & $2.31 \pm 0.05$ & 2.86 & 4453 & (F.P.) \\
FFTG 15 & $22^{\circ} 54.0^{\prime}$ & $46^{\circ} 06.4^{\prime}$ & $2.42 \pm 0.16$ & 0.82 & 4465 & (F.P.) \\
FFTG 16 & $22^{\circ} 45.0^{\prime}$ & $46^{\circ} 06.7^{\prime}$ & $2.30 \pm 0.08$ & 0.95 & 4465 & (F.P.) \\
\hline
\end{tabular}

Note: $\mathrm{HF}=0.88 \pm 0.07 ; n=7$ (excluding FFTG -12 ); $\mathrm{HF}=1.13 \pm 0.70 ; n=8$ (including FFTG -12 ). F.P. $=$ Full Penetration. HFU $=$ micro $\mathrm{cal} / \mathrm{cm}^{2} \mathrm{sec}$ $K=\mathrm{mcal} / \mathrm{cm} \mathrm{sec}{ }^{\circ} \mathrm{C}$.

TABLE 3

Rock Dredges

\begin{tabular}{|c|c|c|c|c|}
\hline Station & Type & $\begin{array}{l}\text { Latitude } \\
(\mathrm{N})\end{array}$ & $\begin{array}{l}\text { Longitude } \\
\text { (W) }\end{array}$ & Results \\
\hline 4 & RD1 & $23^{\circ} 02.9^{\prime}$ & $\begin{array}{l}45^{\circ} 59.5^{\prime} \text { to } \\
46^{\circ} 00.5^{\prime}\end{array}$ & $\begin{array}{l}26 \text { samples retrieved, mostly } \\
\text { glassy volcanics (see dredge } \\
\text { sample descriptions) }\end{array}$ \\
\hline 5 & RD2 & $\begin{array}{l}23^{\circ} 03^{\prime} \text { to } \\
23^{\circ} 04.1^{\circ}\end{array}$ & $\begin{array}{l}45^{\circ} 57.5^{\prime} \text { to } \\
45^{\circ} 58.0^{\prime}\end{array}$ & Dredge empty \\
\hline 7 & RD3 & $23^{\circ} 02.0^{\prime}$ & $\begin{array}{l}45^{\circ} 57.8^{\prime} \text { to } \\
45^{\circ} 59.0^{\prime}\end{array}$ & Dredge empty \\
\hline 8 & RD4 & $23^{\circ} 02.0^{\prime}$ & $\begin{array}{l}45^{\circ} 55.5^{\prime} \text { to } \\
45^{\circ} 57.0^{\prime}\end{array}$ & $\begin{array}{l}5 \text { samples retrieved, highly } \\
\text { altered rocks (see dredge } \\
\text { sample descriptions) }\end{array}$ \\
\hline 9 & RDS & $\begin{array}{l}22^{\circ} 57.0^{\prime} \text { to } \\
22^{\circ} 57.5^{\prime}\end{array}$ & $\begin{array}{l}45^{\circ} 50.5^{\prime} \text { to } \\
45^{\circ} 51.5^{\prime}\end{array}$ & Lost dredge \\
\hline 10 & RD6 & $22^{\circ} 46.0^{\prime}$ & $\begin{array}{l}46^{\circ} 03.0^{\prime} \text { to } \\
46^{\circ} 04.0^{\prime}\end{array}$ & Dredge empty \\
\hline 11 & RD7 & $22^{\circ} 45.5^{\prime}$ & $\begin{array}{l}46^{\circ} 01.5^{\prime} \text { to } \\
46^{\circ} 02.5^{\prime}\end{array}$ & Dredge empty \\
\hline 13 & RD8 & $22^{\circ} 46.3^{\prime}$ & $46^{\circ} 03.8^{\prime}$ & Dredge empty \\
\hline 14 & RD9 & $\begin{array}{l}22^{\circ} 46.0^{\prime} \text { to } \\
22^{\circ} 46.5^{\prime}\end{array}$ & $\begin{array}{l}46^{\circ} 02.6^{\prime} \text { to } \\
46^{\circ} 03.3^{\prime}\end{array}$ & Dredge empty \\
\hline 15 & RD10 & $\begin{array}{l}22^{\circ} 47.0^{\prime} \text { to } \\
22^{\circ} 47.8^{\prime}\end{array}$ & $\begin{array}{l}46^{\circ} 08.0^{\prime} \text { to } \\
46^{\circ} 09.0^{\prime}\end{array}$ & 1 manganese nodule \\
\hline 16 & RD11 & $22^{\circ} 47.0^{\prime}$ & $\begin{array}{l}46^{\circ} 01.0^{\prime} \text { to } \\
46^{\circ} 02.5^{\prime}\end{array}$ & Dredge empty \\
\hline 17 & RD12 & $22^{\circ} 47.0^{\prime}$ & $\begin{array}{l}46^{\circ} 00.5^{\prime} \text { to } \\
46^{\circ} 01.2^{\prime}\end{array}$ & Dredge empty \\
\hline 18 & RD13 & $\begin{array}{l}22^{\circ} 49.0^{\prime} \text { to } \\
22^{\circ} 49.4^{\prime}\end{array}$ & $\begin{array}{l}46^{\circ} 00.1^{\prime} \text { to } \\
46^{\circ} 00.7^{\prime}\end{array}$ & Dredge empty \\
\hline
\end{tabular}

1) It is a large sediment pocket deep enough for spudding in the drill stem.

2) Crustal structure beneath it is similar to North Pond, although the velocities are somewhat lower and therefore closer to regional averages.

3 ) It is on the flank of anomaly 5 . that:

The disadvantages of a drill site at " $A$ " pond are

1) The sediment appears to have undergone some post-depositional faulting.

2) It is close (about $7 \mathrm{~km}$ ) to the largest fracture zone interpreted in the region.

3) HIG collected less information at "A" pond, including less seismic data and no heat-flow data.

\section{SUMMARY}

The very detailed geophysical and geological survey of Atlantic Site 5 successfully delineated a drill site, and alternate drill sites, that have adequate sediment cover to place and set the re-entry hardware on the sea floor.

The site also met the specifications of having normal (for the upper flank of the MAR) bathymetric, gravity,

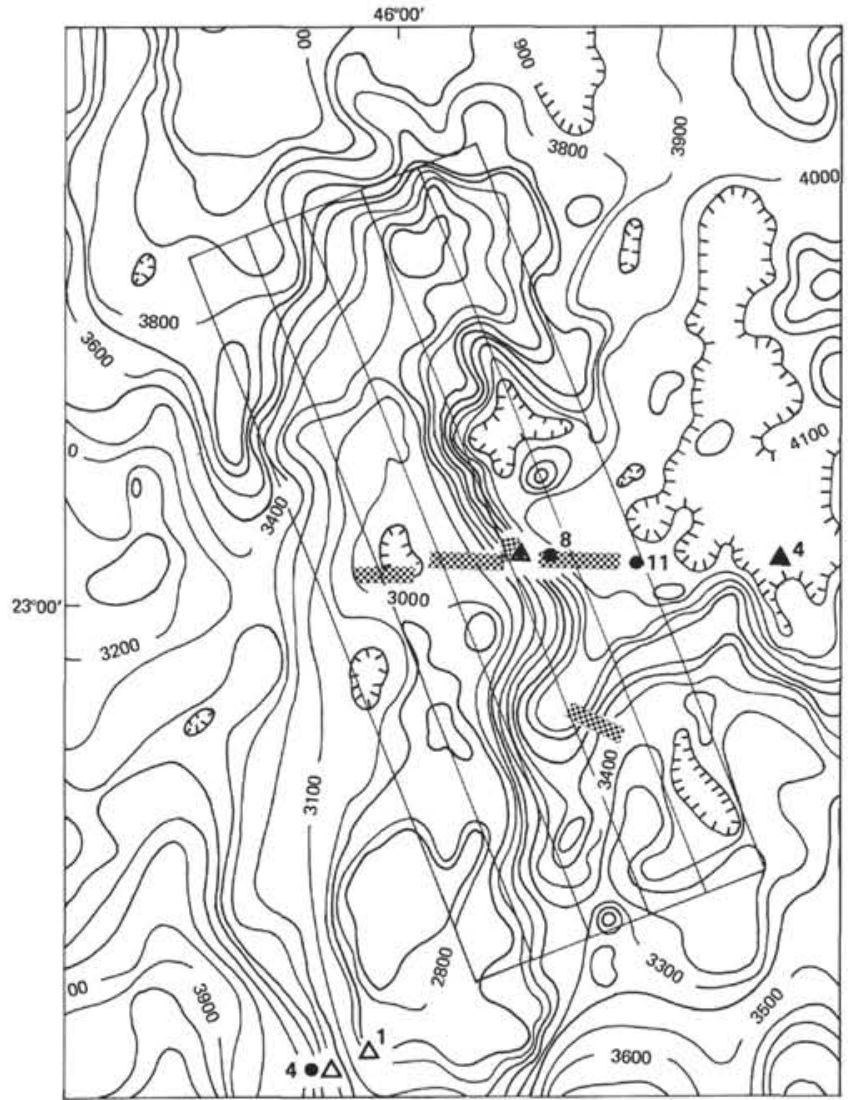

Figure 13. Enclosed portion of Figure 3 showing the locations of successful dredge hauls. The area in the rectangle is the region shown in the block diagram in Figure 14.

and magnetic properties. Although very rugged, the bathymetry was of appropriate average depths, and demonstrated the disposition of topographic grain that would be anticipated. The magnetic anomaly pattern generated by sea-floor spreading was identifiable, and showed that the prime site was on crust formed during the time of magnetic anomaly 4. No major magnetic anomaly offsets occurred through the prime sites; this permits the hope that the east-west bathymetric depression through North Pond was not caused by a major fracture zone. The FAA gravity has not yet been modeled, but has wavelengths and amplitudes that suggest that the anomalies can all be attributed to bathymetry and shallow structure. The dredged rocks were alkalic basalts. Heat flow is low and consistent in the region.

In spite of the apparently "normal" character of this young crust, the explosion seismic data show the crust to be extremely irregular and disorganized. No layering was clearly identified, although a very generalized average crustal model was made that yielded a velocity-depth relationship not unlike what other workers have found around the crest of the MAR. These crustal seismic models for Atlantic Site 5 were, however, based on a very large and detailed data set. It is our feeling, therefore, that the irregular velocity models are an acoustic representation of the nature of young 


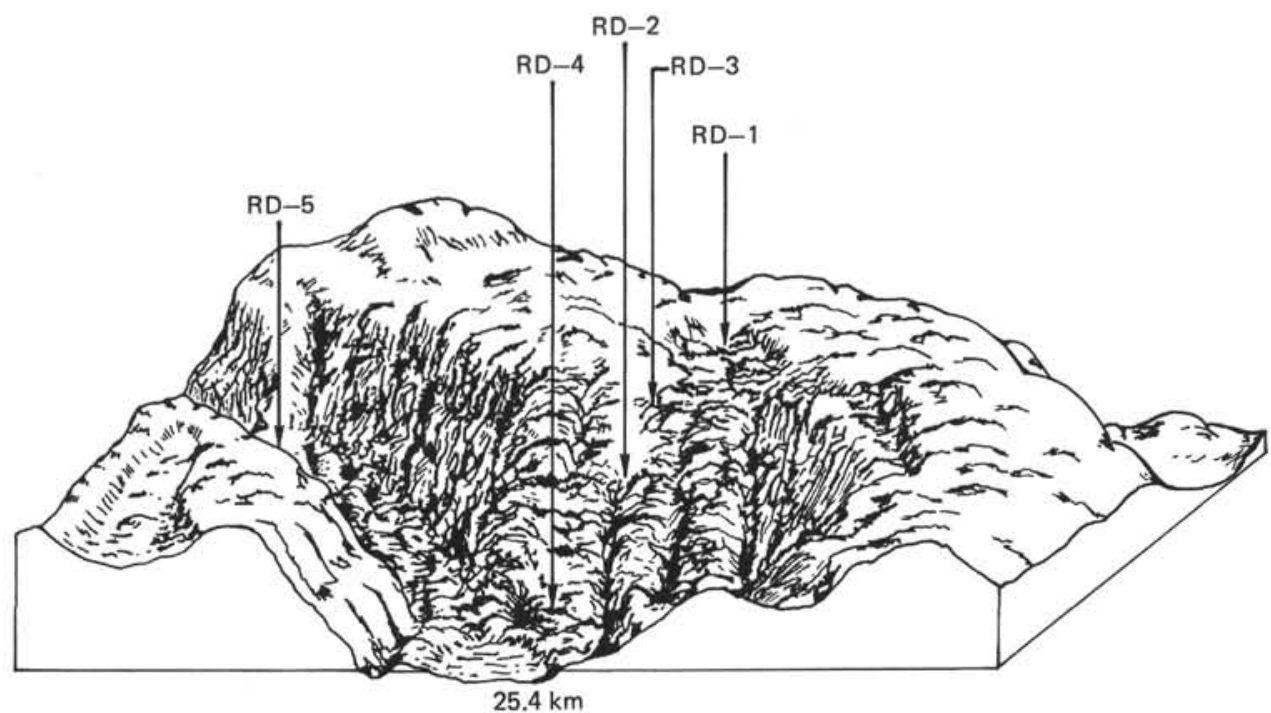

Figure 14. Block diagram showing locations of rock dredges 1 through 5. Vertical exaggeration is $1: 5$.

TABLE 4

Foraminifer Ooze Sample 1.6

\section{Species present: \\ Sphaeroidinellopsis seminulina \\ $S$. subdehiscens subdehiscens \\ Globorotalia multicamerate \\ G. margaritae \\ S. subdehiscens paenedehiscens \\ Globigerina nepenthes}

\section{Absent are:}

Spheroidinella dehiscens

Pulleniatina

Globorotalia tumida

\section{Age range: \\ extinct N.20 \\ extinct N.19 \\ N.17 to N.21 \\ mid N.16 to mid N.19 \\ mid N.17 to mid N.20 \\ N.14 to mid N.19}

beg. N.19

beg. to mid N.17

beg. N.18

Date:

Late Miocene (absence of $S$. dehiscens), probably Zone N.17 (absence of G. tumida, Pulleniatina)

Note: Foraminifers identified and age of sample determined by Johanna M. Resig.

TABLE 5

Petrographic Descriptions and Mineralogy of Selected Rocks From RD-1

\begin{tabular}{|c|c|c|c|c|c|c|c|c|}
\hline \multirow[b]{2}{*}{ Sample } & \multirow[b]{2}{*}{ Texture } & \multicolumn{7}{|c|}{ Mineralogy } \\
\hline & & $\mathrm{pl}$ & $\mathrm{px}$ & ol & $\mathrm{mt}$ & gl & pa & oth \\
\hline \multicolumn{9}{|c|}{ Porphyritic } \\
\hline 1.8 & Vitrophyric & 1 & & $\operatorname{tr}$ & 2 & 10 & 86 & \\
\hline 1.B2 & Vitrophyroc to variolitic & 12 & 3 & & 5 & 35 & 5 & 40 \\
\hline 1.3 & Variolitic & 31 & 13 & & 1 & & 39 & 16 \\
\hline 1.10 & Hyalo-ophitic & 29 & 24 & & 6 & 14 & 7 & 20 \\
\hline 1.2 & Hyalo-ophitic & 37 & 24 & tr & 4 & 8 & 10 & 16 \\
\hline 1.14 & Hyalo-ophitic to hyalopilitic & 44 & 5 & $\operatorname{tr}$ & 2 & 41 & & 7 \\
\hline 1.15 & Intergranular & 45 & 27 & $\operatorname{tr}$ & 4 & $\mathrm{tr}$ & & 23 \\
\hline \multicolumn{9}{|l|}{ Aphyric } \\
\hline 1.5 & Variolitic & 5 & 1 & & 1 & $\mathrm{tr}$ & 80 & 12 \\
\hline 1.9 & Variolitic & 9 & & & 1 & 75 & & 15 \\
\hline 1.12 & Variolitic & 5 & 3 & & tr & 10 & 72 & 10 \\
\hline 1.13 & Variolitic to hyalopilitic & 20 & 1 & & 1 & 62 & & 16 \\
\hline 1.B1 & Hyalo-ophitic & 35 & 29 & & 8 & tr & & 27 \\
\hline 1.16 & Hyalo-ophitic & 30 & 14 & & 6 & 22 & & 28 \\
\hline 1.17 & Hyalo-ophitic & 27 & 12 & & 1 & 17 & & 42 \\
\hline 1.1 & Hyalo-ophitic & 29 & 37 & & tr & $\mathrm{tr}$ & & 33 \\
\hline
\end{tabular}

Note: $\mathrm{pl}=$ plagioclase $; \mathrm{px}=$ pyroxene $; \mathrm{ol}=$ olivine $; \mathrm{mt}=$ magnetite $; \mathrm{gl}=\mathrm{fresh}$ glass; $\mathrm{pa}=$ palagonite $; \mathrm{oth}=$ other (including secondary minerals).
TABLE 6

Chemical Analyses of Samples ${ }^{\mathrm{a}}$ From RD-1

\begin{tabular}{lrrrr}
\hline \multicolumn{1}{c}{ Sample } & 1.9 & 1.13 & 1.14 & \multicolumn{1}{c}{1.16} \\
\hline $\mathrm{SiO}_{2}$ & 46.50 & 46.90 & 45.20 & 44.20 \\
$\mathrm{Al}_{2} \mathrm{O}_{3}$ & 14.06 & 14.21 & 14.56 & 13.15 \\
$\mathrm{Fe}_{2} \mathrm{O}_{3} \mathrm{~b}$ & 11.19 & 10.51 & 9.19 & 10.49 \\
$\mathrm{MgO}$ & 8.48 & 9.53 & 11.23 & 9.98 \\
$\mathrm{CaO}$ & 11.99 & 11.70 & 12.86 & 10.64 \\
$\mathrm{Na}_{2} \mathrm{O}$ & 3.34 & 3.60 & 3.32 & 3.38 \\
$\mathrm{~K}_{2} \mathrm{O}$ & 0.41 & 0.38 & 0.36 & 0.54 \\
$\mathrm{TiO}_{2}$ & 1.68 & 1.68 & 0.94 & 1.76 \\
$\mathrm{MnO}_{2}$ & 0.18 & 0.14 & 0.13 & 0.15 \\
Loss on ignition & 1.98 & 1.06 & 1.27 & 1.50 \\
$\mathrm{Total}_{\mathrm{Fe}}$ & 99.81 & 99.71 & 99.06 & 101.01 \\
$\mathrm{Fe} / \mathrm{Fe}+\mathrm{Mg}$ & 0.60 & 0.57 & 0.49 & 0.55 \\
$\mathrm{Na} 2 \mathrm{O}+\mathrm{K}_{2} \mathrm{O}$ & 3.75 & 3.98 & 3.68 & 3.92 \\
\hline
\end{tabular}

aSamples analyzed by energy-dispersive XRF.

bTotal iron as $\mathrm{Fe}_{2} \mathrm{O}_{3}$.

MAR crust. Only after considerably more aging, if then, will the crust begin to demonstrate layering and a more uniform velocity-depth function.

The fractured and irregular youthful crust is an easily conceived product of episodic lithosphere generation at the rise crest. Recent faulting, demonstrated by layer offsets in many of the sediment ponds, and apparent earthquake activity away from the rise crest or any major fracture zones, suggest that the crust is still, 8 or 10 million years after formation, undergoing radical adjustment, fracturing, and deformation.

We feel that the seismic velocity irregularity of the region of Atlantic Site 5 region is "typical"-as are the other geologic and geophysical properties-of slowspreading crust of less than 10 million years ago.

\section{ACKNOWLEDGMENTS}

We would like to acknowledge the assistance of M. Sexton and J. Kasahara during the seismic refraction analysis, R. Hey for the magnetic anomaly correlations, J. Halunen for 


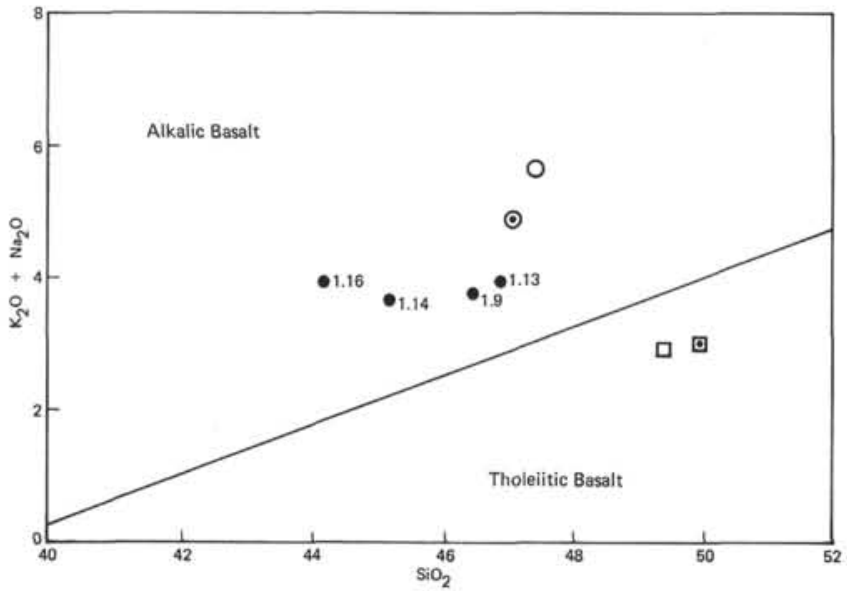

Figure 15. Silica versus total alkalis, showing fields of alkalic and tholeiitic basalt of Macdonald and Katsura (1964). Solid circles are samples from this study; dotted circle is average of alkalic basalt from islands on the MidAtlantic Ridge (Engel and Engel, 1964); open circle is average of oceanic alkalic basalt (Aumento, 1968); dotted square is average of tholeiitic basalt from the MidAtlantic Ridge (Engel and Engel, 1964); and open square is average of oceanic tholeiite (Aumento, 1968).

the heat flow analysis, and J. Resig for the paleontological analysis. Without the enthusiastic cooperation of the officers and crew of the Kana Keoki, the field work could not have been accomplished. The drafting was done by S. Dang and C. McCreery. This work was supported by IPOD Contract CU-H125903A2.

\section{REFERENCES}

Aumento, F., 1968. The Mid-Atlantic Ridge near $45^{\circ} \mathrm{N}$ II basalts from the area of Confederation Peak, Canadian $J$. Earth Sci., v. 5, p. 1-21.

Engel, A. E. J. and Engel, C. G., 1964. Composition of basalt from the Mid-Atlantic Ridge, Science, v. 144, p. 1330 1333.

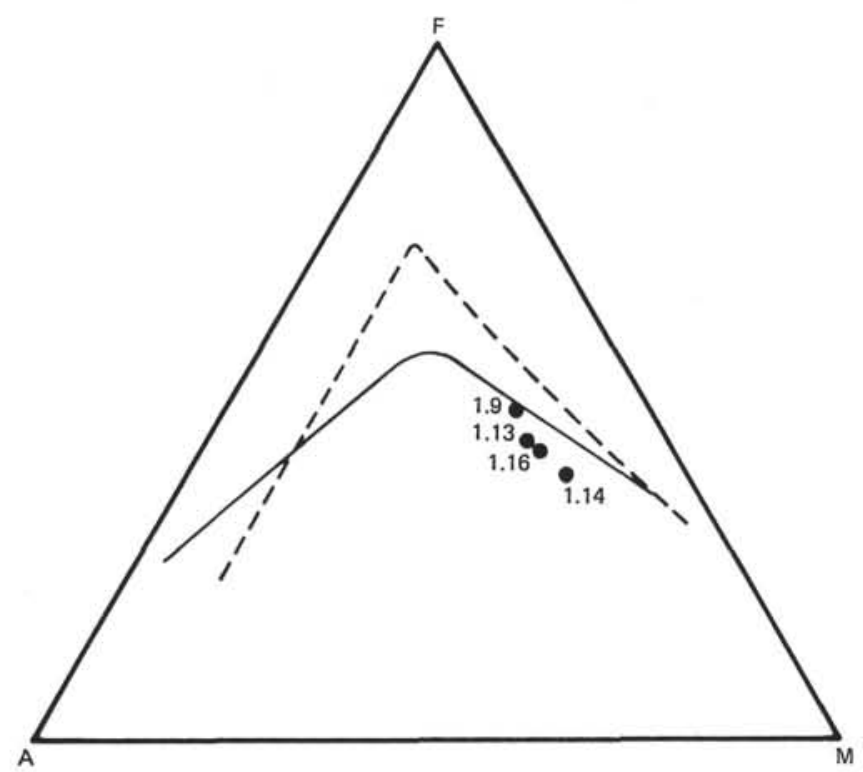

Figure 16. $A F M$ diagram. $\mathrm{A}=\mathrm{Na}_{2} \mathrm{O}+\mathrm{K}_{2} \mathrm{O} ; \mathrm{F}=$ total iron; $M=M g O$, showing the differentiation trends of Hawaiian tholeiitic (dashed line) and alkalic (solid line) basalt (Macdonald and Katsura, 1964).

Macdonald, G. A. and Katsura, T., 1964. Chemical composition of Hawaiian Lava, J. Petrol., v. 5, p. 82-133.

Sutton, G. H., and Kasahara, J., Ichinose, W. N., and Byrne, D. A., 1977. Ocean bottom seismograph development at Hawaii Institute of Geophysics, Mar. Geophys. Res., v. 3 p. 153-177.

van Andel, T. H. and Bowin, C. O., 1968. Mid-Atlantic Ridge between $22^{\circ}$ and $23^{\circ}$ North latitude and the tectonics of mid-ocean rises, J. Geophys. Res., v. 73, p. 1279-1298.

Yeats, R. S., Forbes, W. C., Scheidegger, K. F., Heath, G. R., van Andel, T. H., 1973. Core from Cretaceous basalt, central equatorial Pacific, Leg 16, Deep Sea Drilling Project, Geol. Soc. Am. Bull., v. 84, p. 871-882. 